\title{
Opinion Polls, Political Elites and Party \\ Competition in Postcommunist Bulgaria
}

\author{
Matt Henn \\ Journal of Communist Studies and Transition Politics, \\ Vol. 17 (3), pp. 52-70. 2001.
}

DOI: 10.1080/714003579

\begin{abstract}
This article examines the role of opinion polls in East European countries, and assesses the impact that they have had on the general processes of political democratisation there since the collapse of communism. Certainly, opinion polls have taken a high-profile role in political affairs in these countries over the course of the last decade. Policy-makers, politicians and political parties made much use of polls in the early years of democratic transition, although for various reasons they were received with significant scepticism by each of these users and by citizens alike. This article compares recent research with earlier studies on the use of polls by political elites in countries seeking to consolidate democracy. From recent in-depth interviews conducted with national politicians in Bulgaria, I draw upon a number of examples to examine the ways in which political parties and elites use opinion polls, and their intentions for doing so.
\end{abstract}

When George Gallup first pioneered the use of opinion polling in the USA, he did so with the intention that it would serve to enhance and extend democratic processes and practices by providing a channel through which citizens could participate in political affairs. ${ }^{1} \mathrm{He}$ advocated a 'populist' notion of government, in which voters would have a significant input into decisionmaking. He claimed that opinion polls could provide a useful means through which this might be achieved, by objectively measuring the views of voters, and then communicating these to elected

Matt Henn is a Senior Lecturer at the Nottingham Graduate School for Social Research, Nottingham Trent University. Special thanks are extended to Ognian Shentov and Alexander Stoyanov at the Centre for The Study of Democracy in Sofia, for organising the interviews for this article. 
representatives. Ultimately, polls would help to increase the efficiency of representative government, by making elites more responsive to public opinion, and by facilitating greater popular participation in the political process. $^{2}$ An opposing view can be constructed using Schumpeter's 'competitive elitism' model. ${ }^{3}$ This would suggest that opinion polls are used by political elites to centralise, not decentralise political power. In this way, polls would be commissioned by a political party with the express intention of acquiring information to gain competitive advantage over its political rivals.

This article explores these issues by investigating the role of opinion polling in East European countries, and assessing the impact that polls have had on the general processes of political democratisation over the course of the last decade, following the collapse of communism. Specifically, it examines how political opinion polls are used by political parties and elected representatives, and how they are perceived by these agents and by citizens generally. The article builds upon previous research, ${ }^{4}$ and examines whether there are today any parallels with these early experiences of the use of polls by elected representatives in countries seeking to consolidate democracy. The findings are based upon a series of elite interviews with pollsters and with users of the polls (leading politicians from a variety of political parties) conducted in Bulgaria, December 1998. The purpose of the qualitative interviews is to develop insights into the way that polls impact upon the political process in postcommunist societies. ${ }^{5}$

\section{Public Opinion, Opinion Polls and Political Democratisation}

According to some observers, polls in liberal-capitalist societies do more than provide citizens with knowledge about the political system, about political issues, and about the performance of political leaders. They also enhance the opportunities for citizen influence, and ensure policymakers are sensitive and responsive to the demands of the public. ${ }^{6}$ Others have argued that 'public opinion polling thrives in a democratic environment... that it is the handmaiden of modern democracy ${ }^{7}$ where populations are dependent on governmental provision of public services, and where formalised procedures for monitoring public expression and popular feeling are ordinarily restricted to infrequent elections. Underlying this view of the role of opinion polling is an implicit assumption that the nature of political power in liberal-capitalist societies is essentially pluralistic, with significant scope for popular intervention in decision-making. ${ }^{8}$ It suggests that the political system in these societies is sufficiently flexible to enable opinion polls to operate as links between the electorate and political representatives, and as mechanisms through which citizens can play a meaningful role in political affairs. In this scenario, polls help to strengthen the general processes of political democratisation. 
An alternative view maintains that in liberal-capitalist societies, the political systems are largely closed to the public, with political power monopolised by small elite groups. ${ }^{9}$ For instance, Schumpeter's model of 'competitive elitism' defines democracy as: 'an institutional arrangement for arriving at political decisions in which the individuals acquire the power to decide by means of a competitive struggle for the people's vote'. ${ }^{10}$ Using this characterisation of democracy, the chief concern of those who commission opinion polls is not that they should be used to devolve power to voters, but that they should be used to help gain further political power and influence for themselves. Thus, polls are conducted not to empower wider society, but to sustain the political hegemony of elites. ${ }^{11}$

\section{Polls and Democracy in Liberal-Capitalist Societies}

Undoubtedly, opinion polling plays a significant role within the political process of most liberalcapitalist societies, where it is used by governments, parties and the mass media alike. ${ }^{12}$ However, the extent to which polls complement and improve democratic practice in countries like Britain is unclear. Their role is at best double-edged. On one hand, the political landscape is such that political elites need to be responsive to public opinion in order to retain political power. If they systematically ignore voter concerns then they may be punished at subsequent elections. Political elites may use opinion polls as part of the process through which they establish direct contact with voters to nullify this risk. Polls provide political elites with the intelligence information to: determine when and how to respond to the prevailing mood of the electorate; consider the views and likely responses of voters when designing, marketing, implementing, and modifying party

policies; gain feedback about the public's reactions to these policies, to issues and to events. ${ }^{13}$ In this way, polls fulfil a key function in terms of establishing political linkages between political elites and voters, and in so doing, provide a channel through which the public are able to make some indirect input into the affairs of government.

However, this does not include the control of political elites. Polls do not challenge the dominance and power of political elites. Instead, they provide information with which these elites might devise strategies to successfully compete with rivals to secure political power. In Britain for instance, political parties commission polls to win elections to government office. ${ }^{14}$ In order to meet these objectives, the competing parties aim to sustain the loyalty of traditional core supporters, and to win over groups of floating voters. Thus, polls are used to identify how policies can be packaged and presented to the electorate in order to maximise a party's share of the vote in elections. Furthermore, parties make use of polls by investigating which are the issues upon which 
its rivals are most vulnerable electorally, and which it is itself particularly strong. The party can then benefit from this information by campaigning aggressively on these issues, steering the focus of media and public attention towards them, and consequently shaping the political agenda in ways which undermine the credibility of its rivals, and elevate its own standing amongst the electorate. Because polls perform such a useful and effective role in these respects, parties tend to nurture enduring relationships with the pollsters, and structure polling projects into the heart of their campaigning machinery and strategies. In this way, polls may be said to both facilitate and manipulate the democratic process in liberal-capitalist societies.

\section{Polls in East European Societies: 1945 to 1989}

Observing the changing status and activities of opinion polls in East European societies provides an interesting insight into the way that they both impact upon, and are themselves influenced, by the political process.

\section{Opinion Polls and Communism}

The context for political opinion polling in East European societies could not be more different from liberal-capitalist societies in the period between 1945 and 1989. In communist societies, there was a marked division between the state and society, with virtually no meaningful public input into the political process. Governments were ideologically-driven, with an avowed mission to transform society, ostensibly on behalf of the entire citizenry. In such contexts, there was little scope for opinion polling. Opinion polls were perceived by governing elites as having little or no practical, philosophical or ideological relevance. Stanislaw Kwiatkowski, former Central Committee member of the Polish Communist Party and chief political (and polling) advisor to General Jaruzelski in the 1980s comments that: '[t]he picture of a differentiated society that emerged from the public opinion research did not fit the thesis on the moral and political unity of the nation obligatory at that time' (Kwiatkowski, S. 1989, p.4). ${ }^{15}$

Communist governments throughout Central and East Europe took a rather dim view of social science generally, and of social research methods and opinion polling in particular. As a leading Polish opinion pollster during the communist reign in Poland during the 1980s, Piotr Kwiatkowski ${ }^{16}$ notes:

During the Stalinist period, every attempt to express independent opinion on social or political issues was brutally suppressed. The notion of public opinion was officially condemned and sociology was banned from the universities of all communist countries as a Western 'pseudo-science'. 
Essentially, internal public politics did not exist. Politics was generally only public at the international level, with governments either extending friendship to other communist political systems, or engaged in an ideological offensive against global capitalism. Internally, societies were highly politicised in terms of party membership and public propaganda, but there was a notable absence of 'politics' in the sense of publicly competing interests and adversarial opinions. One-party states were the norm, with political priorities limited to one goal (the emancipation of humankind) while class, and hence class struggle, was not officially acknowledged to exist. There was no effective choice between parties. There were no conflicting ideologies concerning how society and the economy should be run. There were therefore presumed to be no differences amongst citizens in terms of their political values and orientations. ${ }^{17}$ As Webb ${ }^{18}$ explains:

One overriding factor, the predominance of the communist party and its particular philosophy, means that much of the subject matter which was the source of the growth of opinion polling in Western countries... reporting divided opinions in the community on political issues, do not happen.

Where polling did take place, it was usually carefully controlled by the political elites, and met with significant scepticism by the public. ${ }^{19}$ Indeed, political leaders were often highly critical of opinion polls. For instance, the reform period of the Polish October of 1956 was noticeable by the relative openness in the approach of the Gomulka's Polish United Workers' Party (PUWP) to opinion polling. Shortly after however, the government re-imposed censorship and restrictions on the press and the academic community, and in particular, on sociology:

Polish empirical sociologists were publicly denounced as infected with 'pollingmania', and as neglecting a Marxist theory of social consciousness. Questionnaires were censored and very few, if any, copies of results were published. ${ }^{20}$

Furthermore, at a plenary meeting of the Central Committee of the PUWP in 1963, set up to discuss ideological issues in Polish society, a special session was devoted to sociology. Sociologists were criticised for their emphasis on Western methodological approaches, for their apparent concentration on recent Western theoretical achievements, and for their lack of enthusiasm for orthodox Marxist-Leninist accounts of historical development and society. As a result, the directors of the state-owned polling agency, Osrodek Badania Opinii Publicznej (OBOP) were removed from their posts, and the activities of the institute were reorganised and scaled down. ${ }^{21}$ 
Throughout the 1960s and 1970s, polling continued to operate at OBOP, but this was carefully controlled by the Communist authorities, and had a restricted scope of coverage. Political issues were considered by the party leadership to be generally out of bounds for the pollsters, except where these presented a positive image of the party and its programmes, or where they could be manipulated and published for propaganda purposes. ${ }^{22}$ According to Szymondarski, ${ }^{23}$ a former director of OBOP, polls were used by the regime as an instrument for the legitimisation of communist rule:

The polls used by the political elite were restricted in the issues that they surveyed. The elite pretended to be open, but all opposition was banned, ideas of selfgovernment were banned. There were no proper democratic political institutions. The elite only spent money on the polls if the results were favourable to the regime. In this way, the polls helped to prop up the regime, and assist political stability. The main role of the polls was to make up for the democratic institutions which were lacking in Poland, but only in one dimension - the propaganda dimension.

\section{Polls in East European Societies: The Postcommunist Experience}

Since the collapse of communism, political opinion polls have achieved a high-profile status in political affairs throughout Eastern Europe. In previous research, it was revealed that policymakers, politicians and political parties made much use of polls in the early years of democratic transition, although for various reasons they were received with significant scepticism by each of these users and by citizens alike. ${ }^{24}$ In the remaining sections of this article there is a focus exclusively on opinion polling in Bulgaria which is designed to address broader issues concerning the role and impact of polls on the political process in postcommunist countries. This discussion is intended firstly, to indicate the extent to which opinion polls continue to perform an important role in party electioneering in Bulgaria. The second objective is to reveal the underlying rationale that Bulgarian political parties and political elites have in using opinion polls. Are parties genuinely interested in devolving political power directly to citizens, by providing voters with a means through which their views and interests can be heard (and acted upon) by political elites? Or, are polls used for purely instrumental reasons, as part of a party's marketing strategy to increase its political power and influence?

\section{Polls and Political Parties in Postcommunist Bulgaria}

Earlier research ${ }^{25}$ has revealed that, like their counterparts in Western Europe and the USA, political parties in Eastern Europe frequently use publicly-reported polls in their electioneering. Such polls are used to monitor electoral opinion, to build electoral strategies, to identify the issue 
priorities of the electorate and of targeted groups, to modify and shape the image of parties, and to guide focused campaigning (in terms of selecting key geographic areas and electoral groupings).

In Bulgaria, only a minority of political parties have access to sufficient resources to be able to commission their own polling projects. This is largely because of the nature of the party system which impedes the development of strong and sustained party-pollster links of the kind that are noticeable in countries like Britain. The proliferation of parties ${ }^{26}$ results in a situation where demand for the polls as a source of political intelligence to help market the parties cannot be satisfied. ${ }^{27}$ Nonetheless, the political parties are typically very attentive to the messages emerging from opinion polls. Elena Poptodorova, Political Council member of the Bulgarian Euroleft Coalition (KE) ${ }^{28}$ claims that across Bulgaria, political parties observe polling results with a critical interest; this enables them to monitor their own electoral popularity, as well as the state of public support for their political opponents:

I think we all are very, as I say, keen to what opinion polls say and we are also respectful to what sociologists have to say ... The most widespread [type of poll monitored] is popularity or personal image of political leaders. This is something very frequent, very regular I would say.

But polls are often used in a more structured and direct way by the parties than for merely assessing the public's reaction to their performance. As is the case in countries like Britain, parties in Bulgaria occasionally employ polling information to articulate the concerns of voters, and then use this intelligence to guide policy-formation. For instance, the United Democratic Forces (UDF) ${ }^{29}$ commissioned a series of opinion polls in the run-up to the 1997 General Election. The intention was to build an understanding of the public's perception of the incumbent BSP (Bulgarian Socialist Party) government, including voters' general level of satisfaction with its performance in office, and of its individual policies. Furthermore, the polls provided an important source of information in both determining how the UDF should distinguish itself as a real alternative to the BSP government in its pre-election campaign programme, as well as developing its own Agenda 2001, the cornerstone of its post-election reform programme. ${ }^{30}$

Polls also have the potential to undermine policy proposals. For instance, Anastasia Mozer, coleader of the Peoples' Union coalition (NS) and leader of the Agrarian Party, notes how the messages received via the polls convinced politicians to abandon a proposal on land reform following the election of an UDF-led government in 1997. This would have involved amending the constitution to allow for foreign purchase of, and investment in, Bulgarian land. The polls 
indicated that the plans were hugely unpopular with the public, and the Bulgarian Socialist Party mounted a successful campaign in opposition to the proposals: 'Public opinion somehow influenced that. The government thought it wouldn't serve the purpose to agitate people in this way'. ${ }^{31}$

We have seen then, that political actors in Bulgaria often use polls to help decide the focus and structure of policy-positioning. This approach to opinion polling reflects an underlying assumption held by many involved in Bulgarian political affairs that there is a need to reach beyond traditional party structures, and to establish direct communication with voters. Polls are often considered to be a useful mechanism for achieving this goal:

It is impossible to make politics without opinion polls. It is impossible. It is not professional. You have no grounds. You go to party meetings, you meet the people who are of course devoted to the idea - they are very active and so on. But this is not the majority of the people. You have to know about people, how they really think. ${ }^{32}$

This suggests that political parties use polls primarily to compete more effectively within the political arena, rather than to establish a more participatory form of political system. In order to achieve this competitiveness, parties recognise that they need to adopt a flexible approach to the electorate, and opinion polls provide a useful means for achieving this.

One of the major political parties recently developed an innovative opinion polling programme to establish on-going links with voters in preparation for the 1999 local elections. The Bulgarian Socialist Party (BSP) set up a nationally co-ordinated project involving intensive, localised polling research. Local party members and supporters were trained by professional polling agencies in basic opinion polling methodology, and then designed and managed the research themselves. It was intended that the results from these localised studies would complement the national campaigning programme by revealing which issues were of importance to local communities, and how they should be approached and presented. ${ }^{33}$

Another aspect of polling research sometimes undertaken by the political parties, involves using the results to identify the key concerns of the public with the intention of setting the election agenda. This type of research is quite uncommon, as most parties are unable to afford to commission their own polling research. However, the following example provides a useful insight into the level of importance attached to polling by political parties, as well as the importance for 
parties of building close relations with pollsters. The Bulgarian Euroleft Coalition (KE), a relatively new political party, ${ }^{34}$ was able to call upon the services of one of the larger and more established opinion polling agencies, British-Balkan Social Surveys (BBSS), at the 1997 General Election. Two of the company's leading directors have ideological sympathy with the party, and are members of its ruling political council. Elena Poptodorova, one of the KE's leading politicians, explains how a series of local opinion polls conducted by BBSS assisted her campaigning in the run-up to the general election. Having spent virtually all her life in an urban setting but contesting a rural seat, part of her polling strategy entailed gaining a sense of the local electorate's concerns:

I wanted a distinction between rural areas and urban areas. Because this [Sofia] is my area, but my constituency is a strongly rural area . . . Then I wanted to know what are the main issues of concern [of my constituents]. So what should the agenda for the election be ? $^{35}$

The experiences of this research are quite revealing in terms of other ways in which polling intervenes in the political process. For instance, the results guided the candidate's choice of which local and regional issues to focus upon in the pre-election campaign, and also how to mould her general party-policy commitments around these localised concerns in her constituency within the Dobrich region:

My motto for the election was, 'What is good for Dobrich is good for the country'...

I tried to address agriculture in terms of land market restitution of ownership rights, and the peaceful co-existence of traditional co-operatives with the new class of small landholders. ${ }^{36}$

Thus, opinion polls were instrumental in terms of deciding the campaign themes, of emphasising particular types of policy form, and of presenting the candidate's agenda. This conclusion was reinforced when the respondent was asked: 'Is there anything that you learnt from that particular polling information that might help you in your campaigning work in the future?'. The reply indicates that the opinion polls provided the candidate with clear guidance about what her campaign themes should be - to avoid general ideological rhetoric and national and international affairs, but to emphasise instead more pragmatic, immediate, and 'provincial' concerns of the local electorate:

Oh yes. It was that rural areas were less receptive to social democracy, 'Third Way' policies and platforms. Second, foreign policy issues remain rather far from the grassroots. That area [Dobrich], as I say, has been very close to the earth, and less interested in issues like NATO, the European Union, and things like that. ${ }^{37}$ 
The degree of importance attached to the emerging polling data by the candidate was then revealed in a subsequent line of questioning:

Question: So, does this opinion poll information suggest to you that, when campaigning, you should be less concerned with national issues, and more concerned with local issues?

Poptodorova: Exactly. I abandoned the area [of foreign affairs in the election rhetoric] - although this is my profession, and I love discussing these issues. That's how I got deeper into agriculture, which I've never done in all my life.

The respondent was sufficiently sensitive to both the context of recent Bulgarian political history, as well as the messages from the polls, to recognise that campaigning at a deeper ideological level (around a new 'Third Way' programme) would not necessarily be the most effective way of attracting voters whose values were structured around a 'left-right' divide. However, focusing on more pragmatic, immediate issues was revealed by the polls as likely to reap electoral dividends in terms of attracting voters away from the two dominant postcommunist party coalitions in Bulgaria:

Question: You mentioned that many voters in these rural areas were not very receptive to the Third Way approach to politics. Does this mean that when you campaign you avoid talking about the Third Way, and talk instead about issues that the polls suggest to you are likely to win votes?

Poptodorova: Exactly. Because if it is otherwise, again ideology comes forth, and what we still have as a predominant attitude is the bi-polar attitude. In politics it is either BSP or UDF - communism, or anti-communism. Its not termed in that way any longer, which is still a progress . . . Language has changed, but instincts are more or less the same. This is my experience, not try to attack their ideological setup because it takes time. It will take a generation.

Previous research ${ }^{38}$ indicates that in the early period after the fall of communist-led regimes in Eastern Europe, polls had frequently been used by new political parties in their general campaigning strategies, and in a variety of ways. These included guiding party tactics in relation to whether to form or leave coalitions with other parties, and also which electoral groups to target in their campaigning. For the relatively new KE coalition, polls performed similar functions. 
Firstly, in terms of how they would be perceived by voters who were typically predisposed to either the BSP or the UDF:

We used to belong to the BSP and we split in 1996. So to me it was curious to know how would we be viewed [in polls] having left the previous majority and having formed a new party. ${ }^{39}$

The KE also asked questions in the polls specifically about which group of voters might potentially become a 'natural' electoral constituency for the Party. The data which emerged formed an important element of the process through which the Party identified key target groups for focused campaigning - disaffected left-wing traditionalists, as well as the relatively young, the highly educated, and those voters living in urban areas:

The pendulum is still running in extremes. For example, what we found out in the last elections was that some twenty percent of the voters who have never touched the blue ticket, ${ }^{40}$ voted blue this time in 1997 , simply as a protest vote against the BSP. But these are people, as I say who in their natural attitude wouldn't vote for a right wing or extreme right wing party. They just didn't want what they had in the last two years [the BSP government]. This is one segment. Plus people who abstained. I must tell you that hesitating voters who have not made their decision until almost [the] last week of the elections would be less than about $20 \%$ in this country. It's always like that. This is another thing which polls tell us... Usually these [people] are the best-educated people. Urban population mostly. Not too young and not too old. This is the age group of between twenty and fifty. ${ }^{41}$

Polls may also serve a useful function for political parties in terms of candidate-selection, by indicating which personality would most likely maximise the party's share of support in an election. For instance, Nora Ananieva, ${ }^{42}$ former Parliamentary Leader of the Bulgarian Socialist Party and Deputy Leader of the Bulgarian National Assembly, claims that the party's preference for Georgi Pirinski as its 1996 Presidential candidate was in part informed by internallycommissioned opinion polls. These polls suggested that no other BSP candidate could win the election. $^{43}$

In this discussion, we have seen that opinion polls perform various useful functions for Bulgarian political parties in shaping their electioneering strategies. They help the parties to decide upon their policy agendas, which policies should be emphasised publicly during an election campaign, how policy positions should be presented, how to identify potential electoral allies, and candidate 
selection. This has been revealed in previous research across East Europe in the early years of democratic transition, ${ }^{44}$ as well as in the more recent period in Bulgarian political life reported above.

\section{Polls and Manipulation of the Political Process in Postcommunist Bulgaria}

However, the emphasis on opinion polling data has not always been advantageous for individual political parties. For instance, in 1991, polls indicated that some of the major partners within the Union of the Democratic Forces (the Social Democrats, the Greens, and the Agrarians) would stand to maximise their vote if they left the coalition. The polls forecast between 12 and 13 percent electoral support for these parties if they were to campaign outside of the UDF - a more than sufficient level of voter support to pass the four percent electoral threshold necessary to win seats in the National Assembly. In the event, these parties left the UDF, but subsequently failed to achieve this minimum four percent target. This had a dramatic effect on the perception of opinion polls held by both the public and by the political parties:

The split was actually suicide for these [parties]. The main accusation was that the polls provoked those parties to think that they would actually profit from the split off. Which actually did not happen. If UDF had not split at that time they would have had a larger margin over the Socialist Party ${ }^{45}$. The difference was between one and two percent - very, very close. ${ }^{46}$

Thus, while opinion polls may provide obvious benefits to the political parties in their general campaigning strategies and their political marketing, their usage for these purposes is often a source of significant controversy. Two of the enduring features of opinion polls in Bulgaria in both communist and postcommunist times, is that they are widely perceived by political elites, parties and citizens alike as manipulative, and that they are treated with scepticism. As Dimiter Stefanov, Vice Chair of the Democratic Party, claims:

From the beginning [of the democratic transition, 1989] there was widespread scepticism on the work of the political machinery. There was also that scepticism was extended to opinion polls, and early opinion polls, the early agencies were suspected of deliberate misrepresentation. And later the results proved those suspicions were fairly correct. So that didn't bring about much confidence and esteem in the methods of registering and measuring public opinion . . Up until now a large number of people, including myself, have been inclined to doubt the validity of the method that gauges popularity of politicians. ${ }^{47}$ 
It is not only politicians who are sceptics of polls. Many journalists and press editors have reservations about the relationships which often exist between the political parties, newspapers, and the different polling agencies, and of the subsequent manipulation of polls which is alleged to occur:

Every newspaper has its own opinion poll agents ... So we can use only ours. We can read other newspapers' [polls]. The sociological institutes [pollsters] they go to one or other party. They work for them in every election, especially the first one. One of them says that the Communists will win. Another said Democrats will. Everyone said their politicians and their party will win. After that people, including journalists, don't believe [the polls] very much. Everybody knows that these agencies work for these parties and they maybe then say they aren't true. ${ }^{48}$

The remainder of this article focuses on this issue of the manipulation of opinion polls in Bulgarian political life. It is an issue that was raised voluntarily without any prompting in virtually all the interviews conducted for this study.

In earlier research conducted across East Europe, it was found that polls were widely criticised on a number of counts. ${ }^{49}$ Firstly, it is usually only the larger parties who have the resources to commission them. Consequently, smaller parties often attempt to discredit political opinion polls on the grounds that they both facilitate unfair electoral competition, and help contribute to the continued dominance of the larger parties. In countries like Bulgaria where the electoral system sets a minimum percentage threshold of voter support before a party can gain representation in parliament, this is a particularly contentious area for polling. The concern is that polls can help create a bandwagon for a party if the results indicate that it will likely score above this threshold (4\% in Bulgaria), suggesting to voters that their support for the party would not result in a 'wasted vote'. Small, resource-poor political parties are disadvantaged electorally if they are unable to commission their own polls to generate the kind of bandwagons of public support that are possible for the larger, resource-rich parties that can afford opinion polls.

There is also widespread scepticism about the use of polls by those parties who have established relationships with opinion polling companies. This concern is based on the premise that such relationships tend to amount to collusion, in which the objective is to publish misleading results to disorientate rival parties. In Bulgaria, the historical relationship between the Bulgarian Socialist Party (BSP) and British-Balkan Social Surveys (BBSS), has been widely criticised on these grounds, although there is no concrete evidence that such a falsification of poll data has taken place. ${ }^{50}$ The third major concern about the role and impact of polls in postcommunist countries is the 
proliferation of (largely unknown) ad hoc 'ghost' pollsters during election campaign periods. These 'ghost' agencies are usually linked to political parties, and have as their sole purpose the manipulation of electoral outcomes and the general political process. This usually involves artificially elevating the standing of a preferred party (with the intention of creating a bandwagon effect), or reporting a (fictitious) decline in the share of voter support for a rival party (with the intention of undermining its position as an electorally 'credible' party). ${ }^{51}$

The degree of scepticism held by political parties (and even some opinion pollsters) is still significant in Bulgaria a decade after the collapse of communism. Much of this scepticism is reinforced by a number of recent high-profile cases where poll data has been used to poor effect by politicians, and where the data itself may have been misleading. The net effect has been that party strategists have over-emphasised the importance of polls, and have been steered by the poll results into making tactical errors during election contests. In one case, the UDF leadership responded to a series of messages (including those reported by the opinion polls) and opted to insist on an early election in December 1994, rather than accept President Zhelev's invitation to form a government after the resignation of Lieuben Berov's Administration earlier in September. Shortly before the election was called, the polls had presented a variable picture of the state of public opinion - particularly the likely share of support to be gained by the major competing parties and coalition groups. As one senior member of the UDF leadership notes however, those who were in favour of an early election were very selective in their use of polling intelligence to justify their case:

In 1994 the UDF and the then President of the UDF, Mr Filip Dimitrov insisted, and probably believed that the UDF were poised to win a landslide in an election. Or win an absolute majority. In actual fact the UDF won only 26 percent, while the communists won 43 percent. $^{52}$ [There was a] [f]ailure to foresee that discrepancy between expectation and reality. All opinions were backed up by opinion polls ... [and] those in the UDF who chose to indulge in wishful thinking had enough opinion polls to lean on [to support their preference for an early election]. ${ }^{53}$

In another example, the Bulgarian President, Zhelieu Zhelev was persuaded by a close group of advisors to stand as a candidate for the UDF nomination to contest the 1996 presidential election. Against a backdrop in which media-reported polls indicated variable levels of support for the two nominees, the internal poll data presented to Zhelev was relatively conclusive - that he would win the contest if he were to declare his candidacy. Against the advice of some leading colleagues, he opted to stand for the UDF nomination, but ultimately lost by a margin of three to one to Petar Stoyanov. ${ }^{54}$ 
As one senior UDF colleague noted, Zhelev's decision to contest the nomination of the UDF was very much influenced by these internal opinion polls. ${ }^{55}$ The misleading picture these polls presented about his prospects is generally considered by political commentators in Bulgaria to have played a major part in his inability to foresee failure in the election:

President Zhelev was misled by some of his advisors - some of them well known sociologists and people whose opinion mattered. He was misled into participating in a Bulgarian version of primary elections. Opinion polls were showing President Zhelev (as incumbent) as having a fairly high rating in the chance to succeed. While the challenger [Petar Stoyanov] started very modestly, and although his figures rose in the course of the campaign, there was no comparison. The outcome was a disaster for President Zhelev. It was like 60 something as against 30 something. So it is reasonable to ask what kind of actual measuring in public opinion do polls do $?^{56}$

In another recent high-profile case, the polls failed to accurately forecast the outcome of the 1995 mayoral election in Sofia. Throughout the campaign, they predicted a close contest between the BSP candidate, Stefan Sofiyanski, and the main challenger from the UDF. However, contrary to all polling expectations, the outcome was a landslide victory for Sofiyanski with 57.6 percent of the vote. ${ }^{57}$

The inference to be drawn from these recent examples is that political parties and election candidates place particular faith in the ability of opinion polls to measure their prospects in election contests. However, the messages communicated via the polls are often variable, contradictory and misleading. Usage of the polls is also often misjudged. Such data has even been used selectively to support strategic and tactical electoral positions, even if the rationale for using them is flawed. The outcome in such cases may have negative consequences for the parties concerned, as these examples appear to indicate. The explanation for these discrepancies between poll forecasts and election outcomes mirrors those revealed in research conducted in the early 1990s - that there is collusion between some of the opinion pollsters, the political parties, and the mass media organisations who publish the findings. ${ }^{58}$ This collusion even includes manipulation of the polling data. ${ }^{59}$ As a consequence, there is widespread public scepticism of polls:

All of these [opinion polling] companies have connection with political parties. That is the big problem. Because they are not objective. They have influence government influence and opposition influence. That is the position. It is problematic because people don't believe the results of these surveys. Because they 
know that the company has a connection either with the government or with the opposition. ${ }^{60}$

Most observers consider that this issue is less salient in Bulgarian political life now, than it was in the period immediately following the democratic transition, post-1989. However, the problem still significantly mars the reputation, and consequently the development of opinion polling. ${ }^{61}$ Where manipulation of the polls does take place, it appears to serve two functions, both of which are designed to enable a party to gain an advantage over their competitors: to increase their share of voter support at elections, and subsequently their degree of political power. Neither of these functions can be conclusively determined but, through the interviews conducted for this research, both are widely acknowledged to exist. Firstly, the manipulation of polls has the objective to disorientate rival parties. Secondly, publishing misleading accounts of the polls is designed to create a bandwagon of voter support for the party involved. As one interviewee ${ }^{62}$ for this research noted:

One thing I am sure of is that opinion polls, manipulated opinion polls, are considered a useful instrument for shaping the attitudes of the swing vote which is quite large in this country - thirty or forty percent at the latest moment. So [opinion polls] play on the instinct of the swing voters to vote with the expected majority, [and] jump on the bandwagon. Psychologically and sociologically this may be true for the orientation of the swing voters in this country, and maybe throughout the East. I'm not a sociologist myself. But that's what I have heard from specialists. If that is the case that can explain the variety of opinion polls and the disturbing discrepancy between them and some of the [election] results.

\section{Conclusion}

What does the experience of polling in postcommunist Bulgaria, and in particular the way that polls are used by the political parties, reveal about: (a) their impact upon the general political process; and (b) whether George Gallup's ambition for polls - that they should be used to extend democratic practice, create linkages between citizens and political elites, and generally empower voters - is a useful way of understanding the role of opinion polls in postcommunist Bulgaria? The findings reported in this article suggest that political parties continue to demonstrate a keen degree of interest in polls. As with the findings from earlier investigations in other postcommunist countries, ${ }^{63}$ the value attached to polls by the parties, and the usage to which they are put, broadly reflect what has been observed in West European countries. The interest that political parties have in opinion polls reflects more a desire on their part for developing strategies to compete effectively 
with their rivals, than for engaging in a reflective dialogue with citizens to build a more 'participative' style of democracy. In some cases, polling research is reported to the public in order to mislead rather than enlighten voters, with the express purpose of creating a bandwagon effect for the party, and maximising its share of voter support in election contests. Such a cynical approach to the use of opinion polls is widely perceived to exist, and as a consequence, the public, the media and the political parties continue to poll-watch with a sceptical eye.

A decade after the collapse of communism and the movement toward democratic consolidation in Eastern Europe, political elites use opinion polls not to extend political power to citizens, but to concentrate it in their own hands. This suggests that an understanding of how polls impact on the political process in postcommunist countries is better explained in terms of Schumpeter's view of competitive elitism, than Gallup's direct democracy model.

NOTES

${ }^{1}$ G. Gallup, and S. Rae, The Pulse of Democracy (New York: Simon and Schuster, 1940).

${ }^{2}$ G. Gallup, 'Polls and the Political Process - Past, Present and Future', Public Opinion Quarterly, Vol.29 (1965) pp.545-549.

${ }^{3}$ J.A. Schumpeter, Capitalism, Socialism and Democracy (London: George Allen and Unwin Ltd, 1976).

${ }^{4}$ Henn, M 'Polls and the Political Process: The Use of Opinion Polls By Political Parties and Mass Media Organisations in European Post-Communist Societies (1990-95)', Journal of Communist Studies and Transition Politics, Vol.13 No.3 (1997), pp.127-147; Henn, M. (1998a) Opinion Polls and Volatile Electorates: Problems and Issues in Polling European Societies (Aldershot: Ashgate); Henn, M. 'Opinion Polling in Central and Eastern Europe Under Communism', Journal of Contemporary History, Vol.33 No.2 (1998b), pp.229-240.

${ }^{5}$ Earlier investigation suggested that the intervention of polls in Bulgarian political life was not markedly different from that observed in other postcommunist countries (Henn 1997). Nonetheless, while it may be taken that many of the issues revealed about the nature and use of polling in Bulgaria are likely to broadly mirror those occurring elsewhere in Eastern Europe, there is no attempt to make such definitive generalisations.

${ }^{6}$ H. Asher, Polling and the Public (Washington: Congressional Quarterly Inc., 1988).

${ }^{7}$ N.M. Bradburn, and S. Sudman, Polls and Surveys (San Francisco: Jossey-Bass Inc., 1988), p.10.

${ }^{8}$ R. Dahl, Who Governs? Democracy and Power in an American City (New Haven, Conn.: Yale University Press, 1961).

${ }^{9}$ See for instance: R. Miliband, The State in Capitalist Society (London: Weidenfeld and Nicholson, 1969); F. Parkin, Marxism and Class Theory (London: Tavistock, 1979).

${ }^{10}$ Schumpeter, p.269. 
${ }^{11}$ See for instance: Henn, M. (1998a); C. Marsh, ‘Opinion Polls: Social Science or Political Manoeuvre?', in J. Irvine, I. Miles and J. Evans, (eds.) Demystifying Social Statistics (London: Pluto Press Ltd, 1979).

${ }^{12}$ See for instance: ESOMAR, Seminar on "Opinion Polls" in conjunction with the World Association for Public Opinion Research - WAPOR 26th - 28th November (ESOMAR: Strasbourg, 1986); and D. Broughton, Public Opinion Polling and Politics in Britain (Hemel Hempstead: Harvester Wheatsheaf 1995).

${ }^{13}$ R. Worcester, British Public Opinion (Oxford: Blackwell, 1991).

${ }^{14}$ For a full overview of how opinion polls have historically been used by the political parties in Britain, see for instance: M. Abrams, 'Public Opinion, Polls and Parties', Public Opinion Quarterly, Vol.27, (1963), pp.9-18, and 'Opinion Polls and Party Propaganda', Public Opinion Quarterly, Vol.28, (1964), pp.13-19; F. Teer, and J.D. Spence, Political Opinion Polls (London: Hutchinson and Co Ltd, 1973); D. Kavanagh, 'Speaking Truth to Power? Pollsters as Campaign Advisors', in European Journal of Marketing, Vol. 30, No. 10/11 (1996) pp.112-121; Worcester (1991); E. Shaw, 'Labour's Campaigning and Communications strategy 1987-92', Paper presented at the PSA Conference on The 1992 General Election: Voters, Parties and The Media (1992); Broughton (1995).

${ }^{15}$ S. Kwiatkowski, (1989) The Study of Public Opinion in Poland, Unpublished paper, p.4.

${ }^{16}$ P. Kwiatkowski, 'Opinion Research and the Fall of Communism', International Journal of Public Opinion Research, Vol.4, No.4 (1992), p.358.

${ }^{17}$ S. White, 'Public Opinion and Political Science in Postcommunist Russia', in European Journal of Political Research, Vol.27 (1995) p.507.

${ }^{18}$ N. Webb, 'The Current Situation of Opinion Polling Round the World', in ESOMAR, Seminar on Opinion Polls (Amsterdam: ESOMAR, 1986) p.11.

${ }^{19}$ For a discussion of the history of polls in communist societies, and how they were perceived by the public, see: J.A. Piekalkiewicz, Public Opinion in Czechoslovakia, 1968-69 (New York: Praeger, 1972); W. D. Connor, and Z. Y. Gitelman, Public Opinion in European Socialist System. (New York: Praeger, 1977); W.A. Welsh, 'An Overview of the Status of Survey Research in Eastern Europe and the Soviet Union', in W.A. Welsh, (ed.) Survey Research and Public Attitudes in Eastern Europe and the Soviet Union (New York: Pergamon Press, 1981); Kwiatkowski (1992); Henn (1998a).

${ }^{20}$ Kwiatkowski (1992), p.359.

${ }^{21}$ Strzeszewski, Polish Presidential Office, personal interview (Warsaw, May 1991).

${ }^{22}$ J. Dohnalik, OBOP, personal interview (Warsaw, May 1991).

${ }^{23}$ J. Szymondarski, Solidarity Presidential Advisor, personal interview (Warsaw, May 1991).

${ }^{24}$ Henn (1997 and 1998b).

${ }^{25}$ Henn (1998).

${ }^{26}$ At the time of the 1997 General Election, there were 205 parties in Bulgaria, 57 of which eventually contested the election.

${ }^{27}$ A. Stoyanov, Centre for the Study of Democracy, personal interview (Sofia, December 1998). 
${ }^{28}$ E. Poptodorova, MP, Political Council Member, The Bulgarian Euroleft, personal interview (Sofia, December 1998).

${ }^{29}$ The predominantly rightist UDF is one of the two key party players in the postcommunist Bulgarian political arena, the other being the ostensibly leftist BSP.

30 'For the first time on coming to power, [the] UDF presented some plans, Agenda 2001, that gave some general policy objectives and so on in all fields of life (industrial, cultural and so on), based on the things that have to be done in order to make this transition to a democratic society and to a wealthy society. To come out from the crisis' (E. Klain, MP, National Council Member, Union of Democratic Forces, personal interview [Sofia, December 1998]).

${ }^{31}$ A. Mozer, MP, Co-leader, People's Union and Leader, Agrarian Party, personal interview (Sofia, December 1998).

${ }^{32}$ N. Ananieva, Director of the Solidarity Foundation [Bulgarian Socialist Party], and Member of the Executive Bureau of the Supreme Council of the Bulgarian Socialist Party, personal interview (Sofia, December 1998).

${ }^{33}$ N. Ananieva (1998).

${ }^{34}$ The Bulgarian Euroleft Coalition was formed in 1997, and comprises former members of the reform wing of the BSP, together with the Civil Union for The Republic, the Alternative Socialist Union, and the Movement for Social Humanity. At the time of interview, the Euroleft was in the process of negotiation to form a coalition with the Bulgarian Social Democratic Party (who were then members of the United Democratic Forces, UDF) and the LF, Liberal Forum (Poptodorova 1998).

${ }^{35}$ Poptodorova (1998).

${ }^{36}$ Poptodorova (1998).

${ }^{37}$ Poptodorova (1998).

${ }^{38}$ Henn (1997 and 1998b).

${ }^{39}$ Poptodorova (1998).

${ }^{40}$ The UDF. By contrast, the 'Red Ticket' is usually used to describe the BSP.

${ }^{41}$ Poptodorova (1998).

${ }^{42}$ Ananieva (1998).

${ }^{43}$ However, the Constitutional Court ruled Pirinski's nomination out of order on the grounds that he was not a Bulgarian citizen by birth. Eventually, the Party chose Ivan Marazov as its candidate, who lost in the second round of the ballot to the UDF candidate, Petar Stoyanov.

${ }^{44}$ Henn (1997 and 1998a).

45 The Union of the Democratic Forces won $34.4 \%$ of the poll (110 parliamentary seats), compared with the $33.1 \%$ of the vote (106 parliamentary seats) secured by the Bulgarian Socialist Party.

${ }^{46}$ Stoyanov (1998).

${ }^{47}$ D. Stefanov, MP, Vice Chairman, Democratic Party, personal interview (Sofia, December 1998).

${ }^{48}$ Y. Dimitrova, Editor, 24 Hours [daily newspaper], personal interview (Sofia, December 1998).

${ }^{49}$ Henn (1997), pp.133-43. 
${ }^{50}$ Henn (1997), p.138.

${ }^{51}$ Henn (1997), p.139.

${ }^{52}$ The BSP won 43.5 percent (125 seats), and the UDF 24.2 percent (69 seats).

${ }^{53}$ Stefanov (1998).

${ }^{54}$ E. Georgieva, Research Director, Challenge Foundation, personal interview (Sofia, December 1998).

${ }^{55}$ Stefanov (1998).

${ }^{56}$ Stefanov (1998).

${ }^{57}$ Georgieva (1998).

${ }^{58}$ Henn (1997 and 1998a).

${ }^{59}$ This collusion was identified by many of those interviewed during this research, including by politicians, pollsters, and newspaper editors alike. For instance, it was commented upon by: D. Abadjev, MP, United Democratic Forces, personal interview (Sofia, December 1998); Ananieva (1998); A. Angelov, Editor, SEGA [daily newspaper], personal interview (Sofia, December 1998); Stoyanov (1998); A. Todorov, Director, V \& S Institute, and BBSS Gallup, personal interview (Sofia, December 1998); A. Yosiffov, Director, National Public Opinion Research Centre, personal interview (Sofia, December 1998).

${ }^{60}$ Angelov (1998).

${ }^{61}$ Yossifov (1998).

${ }^{62}$ Stefanov (1998).

${ }^{63}$ Henn (1997 and 1998a). 